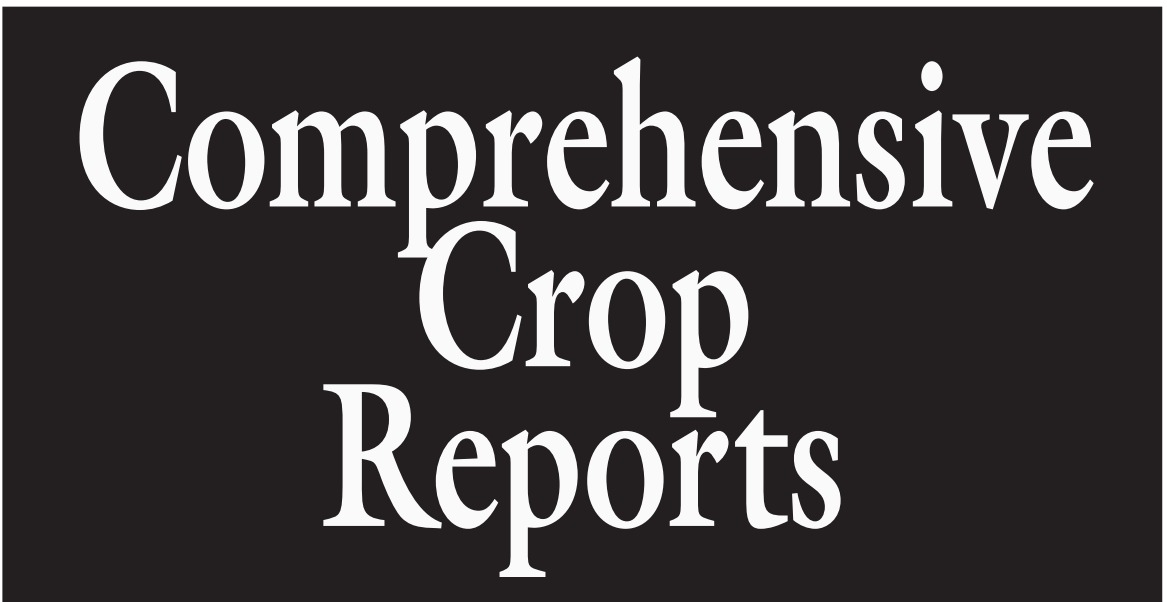

\section{ZZ: A Unique Tropical Ornamental Foliage Plant}

\author{
Jianjun Chen ${ }^{1}$ and \\ Richard J. Henny ${ }^{2}$
}

Additional indeX words. Araceae, drought tolerance, foliage plant production, interior plantscapes, leaf cuttings, low light tolerance, $\mathrm{ZZ}$ plant

Summary. ZZ (Zamioculcas zamiifolia), a member of the family Araceae, is emerging as an important foliage plant due to its aesthetic appearance, ability to tolerate low light and drought, and resistance to diseases and pests. However, little information is available regarding its propagation, production, and use. This report pres ents relevant botanical information and results of our four-year evaluation of this plant to the ornamental plant industry.

\section{Origin and classification}

The genus Zamioculcas [ combination of the generic name Zamia and culcas, the Arabic name for elephant's-

This research was supported by the Florida Agricultural Experiment Station, and approved for publication as Experion as Nursery, Miami, Fla., for providing initial plant materials used in this study and Kelly Everitt for critical reading of this manuscript.

${ }^{1}$ Assistant professor, Mid-Florida Research and Education Center and Dept. of Environmental Horticulture, IFAS, University of Florida, 2725 Binion Road, Apopka, FL 32703 .

${ }^{2}$ Professor, Mid-Florida Research and Education Center and Dept. of Environmental Horticulture, IFAS University of Florida, 2725 Binion Road, Apopka FL 32703 ear plant (Colocasia antiquorum)] was described by Schott (1856) and later by Bentham and Hooker (1883) and Engler and Prantl (1889). It is native to eastern Africa, from Kenya to northeastern South Africa. In fact, this plant has recently been discovered in the wild on rocky, half-shaded ground in both lowland forests and submontane habitats in Tanzania (Doggart et al., 1999). When drought occurs, the leaflets and upper portion of the rachis usually fall, leaving only the swollen reserve of the petiole base, just like pseudobulbs in orchids (Orchidaceae), to tide the plant over until the next rain (Bown, 2000).

Zamioculcas belongs to the fam-

ily Araceae (Bentham and Hooker, 1883; Engler and Prantl, 1889; Schott, 1856); but its relationship to other aroid taxa has been difficult to fathom. Engler (1920) placed it in the subfamily Pothoideae, but Bogner and Nicolson (1991) transferred it to the subfamily Lasioideae. Recently, Mayo et al. (1997) believed it should belong to the subfamily Aroideae. Also, Mayo et al. (1997) further separated 74 genera of the subfamily Aroideae into the perigoniate Aroideae (flowers with a membranous perigon of fused tepals) that contained three genera, Zamioculcas, Gonatopus, and Stylochaeton, and aperigoniate Aroideae (individual flowers naked) that included the rest of 71 genera. Based on palynological data (pollen characteristics), Hesse et al. (2001) classified Zamioculcas and Gonatopusas members of tribe Zamioculcadeae and Stylochaeton as a member of tribe Stylochaetoneae. Zamioculcas has only one recognized species, $Z$. $z a-$ miifolia, and been mainly described by taxonomists (Bentham and Hooker, 1883; Engler and Prantl, 1889; French and Tomlinson, 1981; Grayum, 1990; Griffiths, 1994; Schott, 1856). Its ornamental value has remained obscure until recently being documented as a unique indoor foliage plant (Chen et al., 2002). Zamioculcas zamiifolia has been known by several common names,

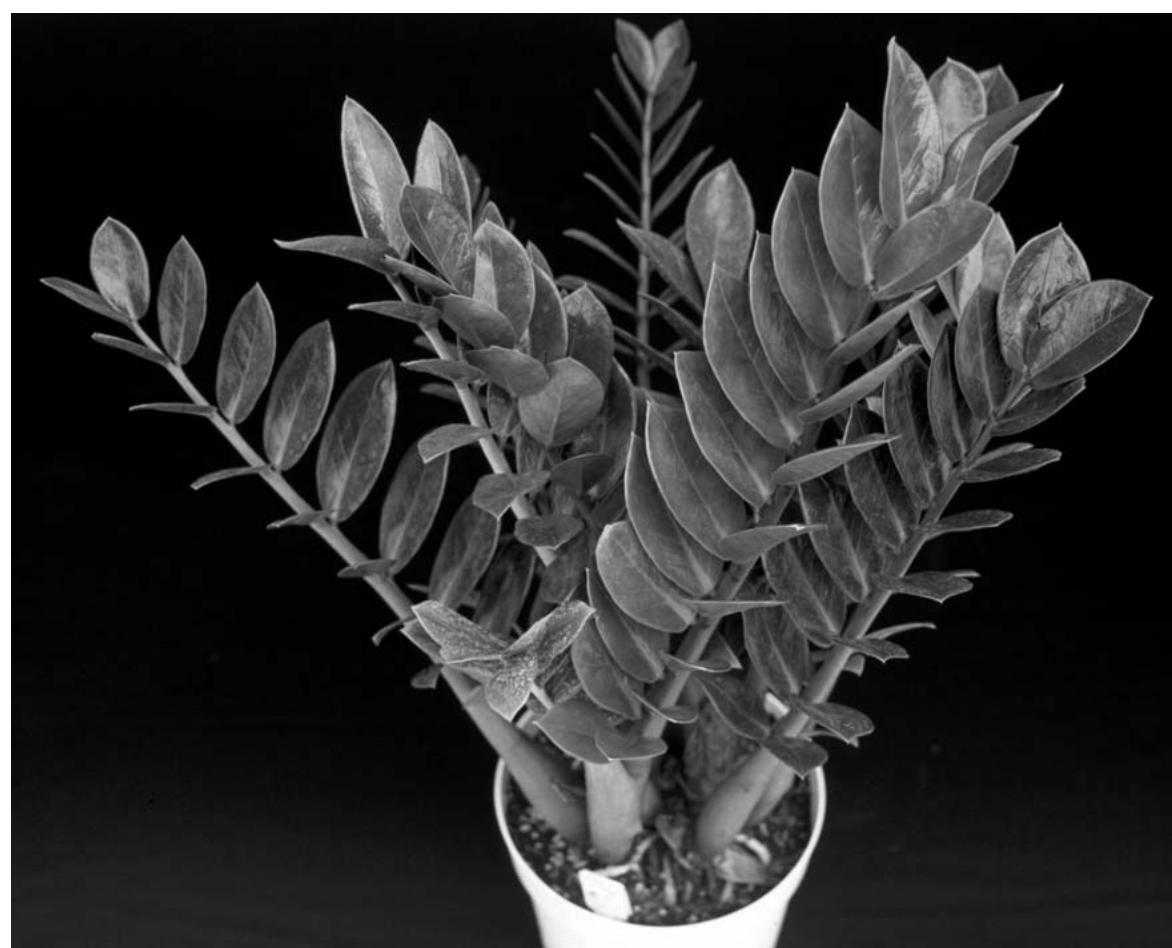

Fig. 1. A finished $\mathrm{ZZ}$ grown in 20-cm-diameter (7.9-inch) container. 


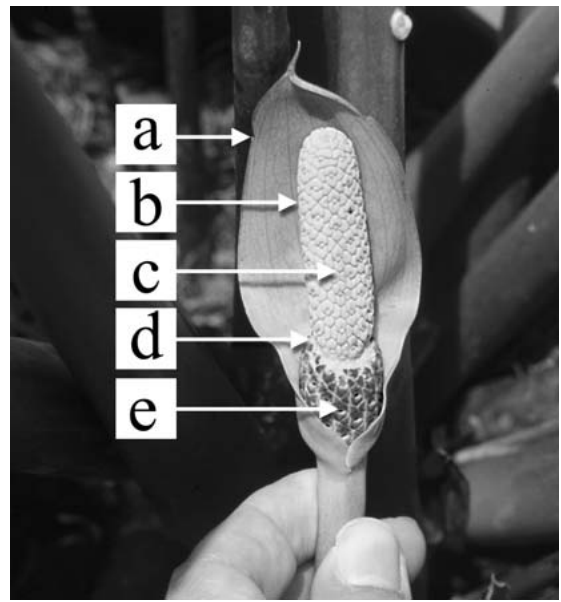

Fig. 2. A ZZ flower: (a) spathe; (b) spadix; (c) male flowers, positioned on the upper portion of the spadix; (d) sterile flowers, the lower central portion of the spadix; and (e) female flowers cover the lower portion of the spadix.

including african coontie, ariod palm, arum fern, cardboard palm, emerald frond, and $\mathrm{ZZ}$ plant. The name $\mathrm{ZZ}$ plant, or simply ZZ, appears to be convenient and is used currently in the foliage plant industry. The Florida Nurserymen and Growers Association (FNGA) listed ZZ among the Florida Plants of the Year in 2002.

\section{Botanical description}

$\mathrm{ZZ}$ is a stemless herbaceous perennial (Liberty Hyde Bailey Hortorium, 1976). Stout, fleshy petioles bearing alternate pinnate leaflets arise directly from thick horizontal rhizomes (Huxley, 1994). Rhizomes vary in size depending on the age of the plant, with a diameter ranging from $0.4 \mathrm{~cm}(0.16$ inch) for those newly formed from leaf cuttings to $10 \mathrm{~cm}$ (3.9 inches) or larger after 2 years of growth. Basal leaves include pinnate and petiole, and petioles are strongly erect, up to $60 \mathrm{~cm}$ (23.6 inches) long (Fig. 1). Leaflets are up to $15 \mathrm{~cm}(5.9$ inches) long and $7 \mathrm{~cm}$ (2.8 inches) wide with a leaf area of about $100 \mathrm{~cm}^{2}(15.5$ inches ${ }^{2}$ ), broadly ovate-elliptic to lanceolate, alternate to semi-opposite, and close to overlapping. They are glossy, dark green and paler beneath, thick and fleshy with veins faintly impressed above. Petioles are thick, markedly swollen at base, pale grey-green, and sometimes faintly mottled green.

Flowering appears to be agedependent, occurring in mature plants during spring and early summer. The inflorescence consists of a spadix enclosed by a modified bract called a spathe (Fig. 2). The spathe is greenish in color, ovate, $7 \mathrm{~cm}$ long, and $3 \mathrm{~cm}$ (1.2 inches) wide. The spadix is a fleshy cylindrical spike, $6 \mathrm{~cm}$ (2.4 inches) long, covered with many small unisexual flowers. Spadices usually contain male flowers on the upper portion and female flowers on the lower portion, with a short constricted zone in between bearing sterile flow-

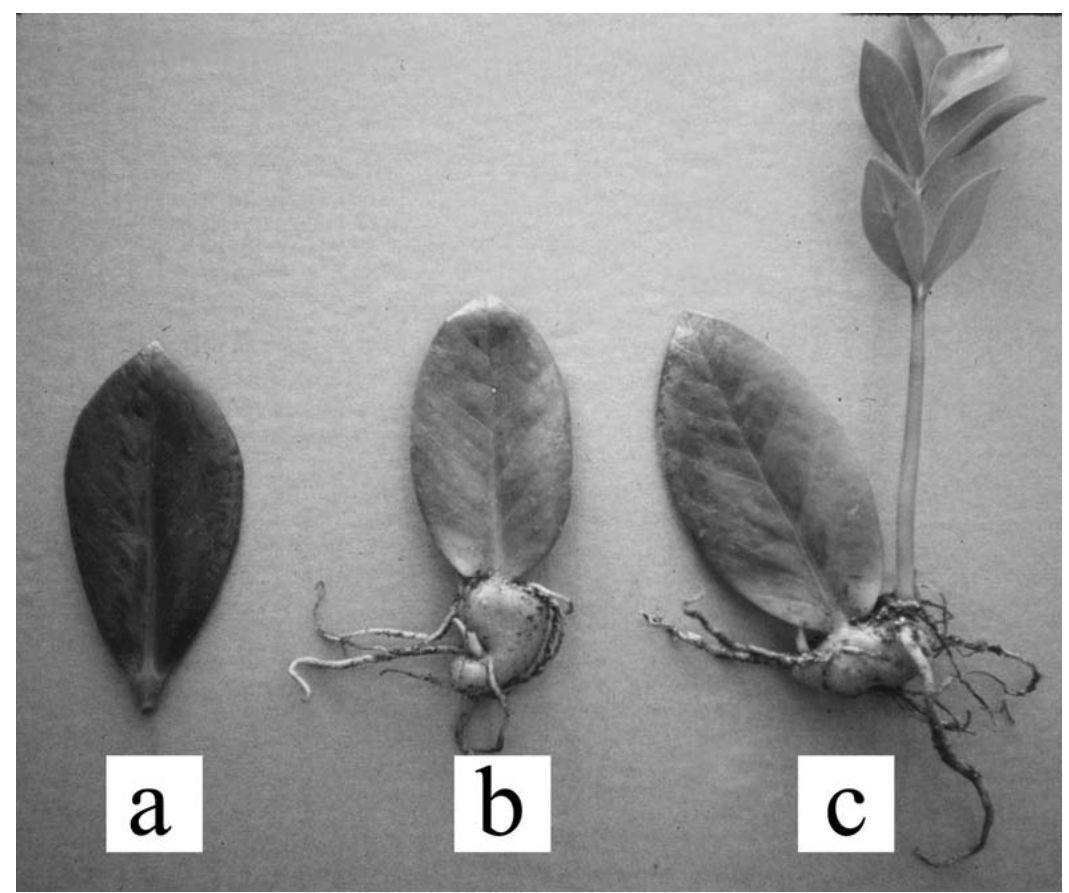

Fig. 3. Rooting leaf cuttings: (a) a leaflet ready for rooting; (b) a rhizome formed at the base of a leaflet as a result of wounding, also note roots produced from the rhizome; and (c) a petiole bearing alternate pinnate leaflets growing up from the rhizome.

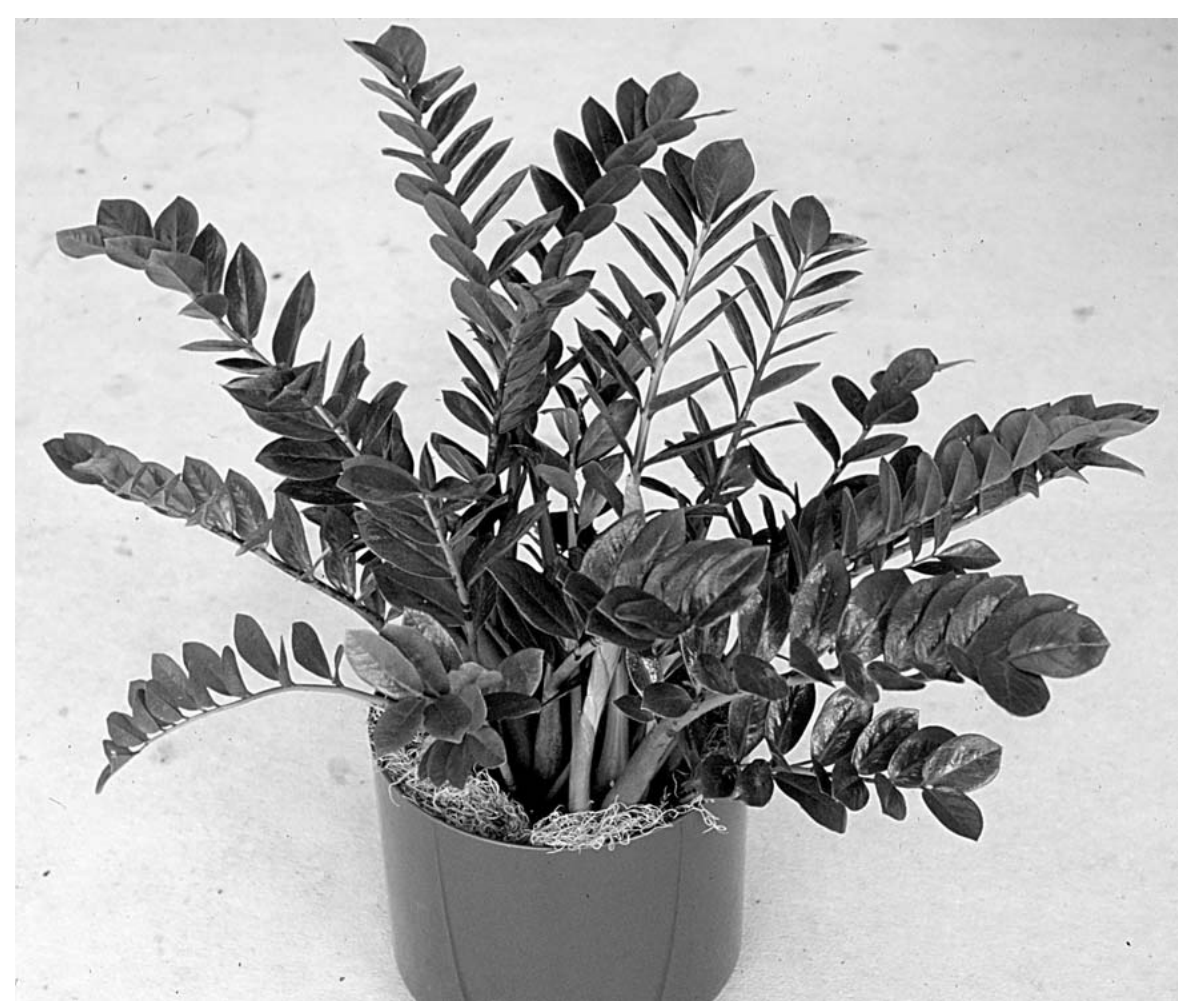

Fig. 4. A ZZ has been indoors for more than 2 years. 
Table 1 . The size, weight, and quantity of $\mathrm{ZZ}$ rhizomes planted in containers for producing marketable plants in 8 to 12 months.

\begin{tabular}{lccc}
\hline $\begin{array}{c}\text { Container size } \\
{[\mathrm{cm} \text { (inches) }]^{\mathrm{z}}}\end{array}$ & $\begin{array}{c}\text { Rhizome size } \\
(\text { length } \times \text { width }) \\
(\mathrm{cm})\end{array}$ & $\begin{array}{c}\text { Rhizome } \\
\text { fresh wt } \\
(\mathrm{g})\end{array}$ & $\begin{array}{c}\text { Rhizomes } \\
\text { per container } \\
(\text { no. })\end{array}$ \\
\hline $10(3.9)$ & $2 \times 2$ & $4-5$ & $2-3$ \\
$15(5.9)$ & $2 \times 2$ & $4-5$ & $4-5$ \\
& $4 \times 2.5$ & $10-15$ & $2-3$ \\
$20(7.9)$ & $4 \times 2.5$ & $1-15$ & $3-4$ \\
& $5 \times 3.5$ & $30-40$ & $2-3$ \\
$25(9.8)$ & $4 \times 2.5$ & $10-15$ & $4-5$ \\
& $5 \times 3.5$ & $30-40$ & $3-4$ \\
\hline
\end{tabular}

${ }^{\mathrm{z}} 1.0 \mathrm{~cm}=0.39$ inch.

y $28.35 \mathrm{~g}=1 \mathrm{oz}$.

ers. The plant has starchy pollen with a diameter of $60 \mu \mathrm{m}$ (Grayum, 1985) suggesting that beetles (Staphylinidae) are the probable pollinators. Seeds are ellipsoid; embryos are large and rich in starch. Endosperm is nearly absent, present only as a few cell layers at chalazal end (Mayo et al. 1997).

$\mathrm{ZZ}$ is a diploid species $(2 \mathrm{n}=34)$ with an unusual base chromosome number of $x=17$ (Jones, 1957). Jones (1957) also reported that chromosomes were large, at least $13.6 \mu \mathrm{m}$ in $\mathrm{ZZ}$ compared to 3 to 6 $\mu \mathrm{m}$ found in other members of the family Araceae (Ramachandran, 1978). Recently, one variant with variegated leaflets has appeared in the trade and is probably derived from the selection of sports. No breeding activities thus far have been documented for improving this plant.

\section{Ornamental value}

The ornamental value of $\mathrm{ZZ}$ lies in its unique appearance, ability to grow under low light conditions, and tolerance to drought stress. It bears little resemblance to any other members of the family Areacea. ZZ has pinnate leaves, terete (cylindrical and tapering) petioles, and looks similar in shape to the cardboard cycad (Zamia furfuracea), which is why it has common names of ariod palm or cardboard palm. Its naturally glossy leaves are so shiny that the plant appears to have been polished.

$\mathrm{ZZ}$ is among the low light tolerant foliage plants such as snake plant (Sansevieria trifasciata) and cast-iron plant (Aspidistra elatior). It is easily maintained and adds stalks and new leaves under interior low light environments. Our recent study suggests ZZ can grow indoors under light level as low as $4 \mu \mathrm{mol} \cdot \mathrm{m}^{-2} \cdot \mathrm{s}^{-1}(25.0 \mathrm{fc})$. Compared to plants grown indoors under light levels of $16 \mu \mathrm{mol} \cdot \mathrm{m}^{-2} \cdot \mathrm{s}^{-1}(100.0$ fc) or higher, plants under light levels of $4 \mu \mathrm{mol} \cdot \mathrm{m}^{-2} \cdot \mathrm{s}^{-1}$ grow slower and have smaller leaflets, averaging $20 \mathrm{~cm}^{2}(3.1$ inch $^{2}$ ) in $4 \mu \mathrm{mol} \cdot \mathrm{m}^{-2} \cdot \mathrm{s}^{-1}$ versus $30 \mathrm{~cm}^{2}$ $\left(4.7\right.$ inch $\left.^{2}\right)$ or larger in $16 \mu \mathrm{mol} \cdot \mathrm{m}^{-2} \cdot \mathrm{s}^{-1}$. However, the overall form and appearance remains aesthetically pleasing. We seldom observed leaflet drop under interior conditions because individual leaf longevity is at least 6 months.

Another important characteristic of $\mathrm{ZZ}$ is its ability to tolerate drought stress. Our studies have shown that it can survive extremely well under interior low light levels from $4 \mu \mathrm{mol} \cdot \mathrm{m}^{-2} \cdot \mathrm{s}^{-1}$ to $16 \mu \mathrm{mol} \cdot \mathrm{m}^{-2} \cdot \mathrm{s}^{-1}$ for 4 months without additional water. Moreover, none of the leaves wilted or turned yellow or necrotic. The drought tolerance probably has evolved from intensive selection pressure of this species during the Neogene and Quaternary Periods when the African flora was severely impoverished by widespread aridity (Raven and Axelrod, 1974). The waxy and shiny leaves, fleshy stems, and the thick rhizomes are likely consequences of the selection as the leaves have extremely low rates of transpiration and rhizomes can reserve water against drought. Additionally, no diseases or pests have been found on this plant in production and interiorscapes.

\section{Propagation}

$\mathrm{ZZ}$ is mainly propagated vegetatively through rhizome division or leaf and petiole cuttings. Although botanically called rhizomes, the form and shape of the rhizomes resemble tubers. Propagation through division is accomplished by separating individual rhizomes, sorting them based on size, and planting the similar-sized rhizomes into containers filled with a substrate. Suitable substrates are $60 \%$ sphagnum peat, $20 \%$ perlite, and $20 \%$ vermiculite by volume, or $55 \%$ sphagnum peat, $25 \%$ pine bark, and $20 \%$ perlite. Other combinations of sphagnum peat, bark, vermiculite, perlite, or coir may be used as long as substrates have a bulk density of 0.15 to $0.8 \mathrm{~g} \cdot \mathrm{cm}^{-3}\left(0.1\right.$ to $\left.0.5 \mathrm{lb} / \mathrm{ft}^{3}\right)$ based on the dry weight, total porosity of $50 \%$ to $75 \%$, container capacity of $20 \%$ to $60 \%$ by volume, moisture content of $50 \%$ to $75 \%$, air space of 10 to $20 \%, \mathrm{pH}$ of 5.5 to 6.5 , and electrical conductivity of 1.0 to $2.0 \mathrm{dS} \cdot \mathrm{m}^{-1}$ when bulk solution is extracted using the pour-through method (Yeager et al., 1983). One to five rhizomes per container are planted depending on rhizome and container sizes.

To propagate from leaf cuttings, leaflets are inserted singly in medium filled cavities of plastic trays that have either 50 or 72 cells. Leaflets can also be rooted in $10-\mathrm{cm}$-diameter containers filled with aforementioned substrates at four leaflets per container. Leaflets may also be cut into several pieces and propagated by placing the wounded side into the substrate. The cavity trays or containers are placed on benches in a shaded greenhouse and enclosed in polyethylene tents with a mist as described by Hartmann et al. (1990) or without an enclosed tent but with well moistened-container substrates (container capacity of $60 \%$ to $80 \%$ ). The shadehouse temperatures should be maintained at 24 to $32{ }^{\circ} \mathrm{C}(75.2$ to $89.6^{\circ} \mathrm{F}$ ), relative humidity from 60 to $100 \%$, and photosynthetically active radiation (PAR) at 100 to 200 $\mu \mathrm{mol} \cdot \mathrm{m}^{-2} \cdot \mathrm{s}^{-1}(520.0$ to $1046.0 \mathrm{fc})$. Callus will form around the main vein in 2 weeks after sticking. A small rhizome (tuber) will become visible in another 2 weeks; l week later, roots will appear in the tuber. One month after the rhizome is visible, a petiole bearing alternate pinnate leaflets will emerge from the container substrate (Fig. 3). Rooting hormone application is not necessary in $\mathrm{ZZ}$ propagation.

Petioles can be cut to about 10 $\mathrm{cm}$ in length and rooted in $10-$ or 15-cm-diameter container at three or five petioles per container, respectively. However, petiole cuttings do not offer any advantage over leaf cuttings as they take more time to form callii and rhizomes. This is because rhizomes will be produced only after the entire cutting surface of the petiole has been covered by callus tissue, which takes more than a month depending on the diameter of petiole. 


\section{Production}

$\mathrm{ZZ}$ can be produced in 10 to $25 \mathrm{~cm}$ (3.9 to 9.8 inches) diameter, well-drained containers. However, ZZ is a slow-growing plant even under favorable production conditions. Thus, the number and size of rhizomes in relation to container sizes becomes important in determining how much time is needed to produce marketable plants. We emphasize rhizomes here because leaf-cutting generated plants are based on the rhizomes. The larger the rhizome, the more shoots will be produced. In general, marketable plants could be produced in 8 to 12 months after rhizomes are planted in corresponding containers as recommended in Table 1. Containers may stay fairly close at the beginning of planting but should be placed 10,20 , 30 , or $40 \mathrm{~cm}(3.9,7.9,11.8$, or 15.7 inches) apart from the edge of each pot for 10-, 15-, 20-, or 25-cm-diameter $(3.9,5.9,7.9$, or 9.8 inches $)$ containers, respectively.

LIGHT. ZZ plant is adaptable to light levels ranging from 4 to 1,200 $\mu \mathrm{mol} \cdot \mathrm{m}^{-2} \cdot \mathrm{s}^{-1}(25.0$ to $6,360.0 \mathrm{fc})$. However, the preferred light level for commercial production ranges from 283 to $472 \mu \mathrm{mol} \cdot \mathrm{m}^{-2} \cdot \mathrm{s}^{-1}(1,500.0$ to $2,501.6 \mathrm{fc}$ ). More stalks emerge from rhizomes under the production light levels, thus, larger plants will be produced.

Temperature AND RELATIVE HUMidITY. ZZ can grow at a temperature range of 15 to $38^{\circ} \mathrm{C}(59.0$ to 100.4 $\left.{ }^{\circ} \mathrm{F}\right)$, but optimum growth takes place with air temperatures between 18 and $32{ }^{\circ} \mathrm{C}\left(64.4\right.$ and $\left.89.6^{\circ} \mathrm{F}\right)$ and media temperatures 20 and $28^{\circ} \mathrm{C}$ (68.0 and $82.4^{\circ} \mathrm{F}$ ). Relative humidity in shaded production greenhouses should range from 50 to $100 \%$. During winter, temperatures should not be lower than 10 ${ }^{\circ} \mathrm{C}\left(50.0^{\circ} \mathrm{F}\right)$ because plant growth will stop and chilling injury may occur.

WATER AND FERTILIZER. Although $\mathrm{ZZ}$ is exceptionally drought-tolerant, the media should remain moist (container capacity of $50 \%$ to $80 \%$ ) during production. If shaded greenhouse temperatures range from 15 to $20^{\circ} \mathrm{C}$ $\left(59.0\right.$ to $\left.68.0^{\circ} \mathrm{F}\right)$ during the winter, the substrate should be slightly dry before watering. Either drip or sub irrigation is preferred as overhead irrigation leaves water residues on glossy leaflets that affect plant's appearance.

ZZ plants do not have high nutri- ent requirements. If controlled-release fertilizers such as Osmocote 18-6-12 with micronutrients $(18.0 \mathrm{~N}-2.6 \mathrm{P}-$ 10.0K, 8-9 months; The Scotts Co., Marysville, Ohio) are used, $4,5,8$, or $\log (0.14,0.18,0.28$, or $0.35 \mathrm{oz})$ can be either surface applied or incorporated into 10-, 15-, 20-, or 25-cm-diameter containers, respectively. When water-soluble fertilizers with micronutrients are used, we recommend nitrogen $(\mathrm{N})$ at $200 \mathrm{mg} \cdot \mathrm{L}^{-1}(\mathrm{ppm})$ for drip irrigated plants weekly and 100 to 150 $\mathrm{mg} \cdot \mathrm{L}^{-1}$ for subirrigated plants. Growers should monitor soluble salt levels of container substrates regularly using the pour-through method (Yeager et al., 1981). If electrical conductivity (EC) readings are below $1.0 \mathrm{dS} \cdot \mathrm{m}^{-1}$, additional fertilization is needed; whereas if EC readings are higher than 3.0 $\mathrm{dS} \cdot \mathrm{m}^{-1}$, growers should reduce either the frequency or amount of fertilizer applications.

INSECTS AND DISEASES. No disease or pest problems have been reported in either production or interior use. However, root rot may occur if plants grow in poorly aerated media with excessive water for an extended period of time. As mentioned previously, its characteristics, such as waxy and shiny leaves, fleshy stems, and thick rhizomes, have determined that $\mathrm{ZZ}$ should be grown in well aerated media, usually with total porosity of $50 \%$ to $75 \%$ and air space $10 \%$ to $20 \%$.

Production strategies. Due to its slow-growing nature, the strategy for ZZ production typically has one group of growers specializing in propagation and the other group focusing on finished plant production. Some growers prefer to conduct both operations. Propagation involves rooting cuttings, rhizome production, and marketing rhizomes based on size. Growers interested in finished plants would plant different sizes of rhizomes in appropriate containers as suggested in Table 1, produce finished plants, and market them to interiorscapers.

\section{Transportation and Interior use}

Since leaflets of $\mathrm{ZZ}$ plants are naturally glossy, no polish is needed. Finished plants are usually placed in paper sleeves and shipped in refrigeration at a temperature of 12 to $18^{\circ} \mathrm{C}$ $\left(53.6\right.$ to $\left.64.4^{\circ} \mathrm{F}\right)$. Once arriving at the market, plants should be placed in interior light levels of $4 \mu \mathrm{mol} \cdot \mathrm{m}^{-2} \cdot \mathrm{s}^{-1}$ or higher. Plants produced in 10- to 15 $\mathrm{cm}$-diameter containers can be placed on office desks or table tops, but 20- or 25-cm-diameter containers are placed on the floor, even in corners where light levels are low. ZZ can also be used as pseudo bonsai or in a combination planter. The average height of most of the plants is about 40 to $80 \mathrm{~cm}$ ( 15.7 to 31.5 inches), and the plant may have a wide spread of 50 to $100 \mathrm{~cm}$ (19.7 to 39.4 inches). Larger plants will have a 1 to $1.5 \mathrm{~m}(3.3$ to $4.9 \mathrm{ft})$ overall spread (Fig. 4). ZZ works well as an accent plant in areas where it can spread its wings. Plants should not be fertilized if EC readings are $1.0 \mathrm{dS} \cdot \mathrm{m}^{-1}$ or higher. Media should be maintained slightly dry in interior conditions. Temperatures of 20 to $24^{\circ} \mathrm{C}\left(68.0\right.$ to $\left.75.2^{\circ} \mathrm{F}\right)$ are most appropriate.

\section{Conclusion}

Interior plantscapers and homeowners have been looking for unusual plants that can be used indoors to provide a unique look, and commercial growers are always looking for novel items to offer their customers something new. ZZ has a prehistoric look reminiscent of cycads with glossy, shining leaves, and tolerates low light and drought. No disease or insect problems have been reported to date. ZZ should be used by homeowners and commercial firms for indoor decoration and interiorscaping.

\section{Literature cited}

Bentham, G. and J.D. Hooker. 1883. Genera Plantarum. vol. 3. L. Reeve and Co., London.

Bogner, J. and D.H. Nicolson. 1991. A revised classification of Araceae with dichotomous keys. Willdenowia 21:35-50.

Bown, D. 2000. Aroids: Plants of the arum family. $2^{\text {nd }}$ ed. Timber Press, Portland, Ore.

Chen, J., R.J. Henny, and D.B. McConnell 2002. Development of new foliage plant cultivars, p. 446-452. In: J. Janick and A Whipkey (eds.). Trends in new crops and new uses. ASHS Press, Alex., Va.

Doggart, N., L. Joseph, J. Bayliss, and E. Fanning. 1999. Manga Forest Reserve: A biodiversity survey. E. Usambara Conserv. Area, Tanga, Tanzania, Mgt. Programme Technical Paper 41

Engler, A. and K. Prantl. 1889. Araceae. Dienaturlichen Pflanzenfamilien 2: 102-159. 


\section{Comprehensive Crop Reports}

Engler, A. 1920. Araceae-Pars generalis et index familiae generalis. In: A. Engler (ed.). Das Pflanzenreich 74 (IV. 23A):1-71.

French, J.C. and P.B. Tomlinson. 1981 Vascular patterns in stems of Araceae: Subfamily Pothoideae. Amer. J. Bot. 68 713-729.

Grayum, M.H. 1985. Evolutionary and ecological significance of starch storage in pollen of the Araceae. Amer. J. Bot. 72: 1565-1577.

Grayum, M.H. 1990. Evolution and phylogeny of the Araceae. Ann. Mo. Bot. Gard. 77:628-697.

Griffiths, M. 1994. Index of garden plants Timber Press, Portland, Ore.
Hartmann, H.T., D.E. Kester, and F.T. Davies. 1990. Plant propagation: Principles and practices. $5^{\text {th }}$ ed. Prentice Hall. Englewood Cliffs, N.J.

Hesse, M., J. Bogner, H. Halbritter, and M. Weber. 2001. Palnology of the perigoniate Aroideae: Zamioculcas, Gonatopus, and Stylochaeton (Araceae). Grana 40:26-34.

Huxley, A. 1994. The new royal horticultural society dictionary of gardening. Macmillan, London.

Jones, G.E. 1957. Chromosome numbers and phylogenetic relationships in the Araceae. PhD diss., Univ. Va., Charlottesville.

Liberty Hyde Bailey Hortorium. 1976. Hortus third. Macmillan, New York.

Mayo, S.J., J. Bogner, and P.C. Boyce.
1997. The genera of Araceae. Royal Bot. Garden, Kew.

Ramachandran, K. 1978. Cytological studies on south Indian Araceae. Cytologia 43: 289-303.

Raven, P.H. and D.I. Axelrod. 1974. Angiosperm biogeography and past continental movements. Ann. Mo. Bot. Gard. 61:539-673.

Schott, H.W. 1856. Synopsis Aroidearum. Typis congregationis mechitharisticae, Vienna.

Yeager, T.H., R.D. Wright, and S.J. Donohue. 1983. Comparison of pour-through and saturated pine bark extract $\mathrm{N}, \mathrm{P}, \mathrm{K}$, and $\mathrm{pH}$ levels. J. Amer. Soc. Hort. Sci. 108:112-114. 